\title{
CUTA Gene
}

National Cancer Institute

\section{Source}

National Cancer Institute. CUTA Gene. NCI Thesaurus. Code C114653.

This gene may play a role in acetylcholine metabolism. 